\title{
Voting in New Zealand local government elections: the need to encourage greater voter turnout
}

\section{Commonwealth Journal of Local Governance \\ Issue 24: June 2021}

http://epress.lib.uts.edu.au/ojs/index.php/cjlg

\section{Andy Asquith}

School of Management

Massey University

Palmerston North 4442

New Zealand

Email: a.asquith@massey.ac.nz

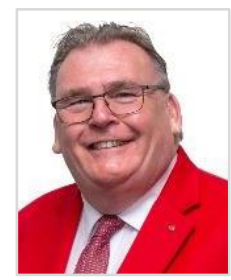

\section{Karen Webster}

School of Clinical Sciences

Auckland University of Technology

Auckland 0632

New Zealand

Email: karen.webster@aut.ac.nz

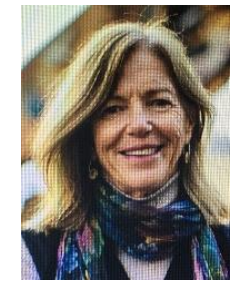

\section{Andrew Cardow}

School of Management

Massey University

Palmerston North 4442

New Zealand

Email: a.cardow@massey.ac.nz

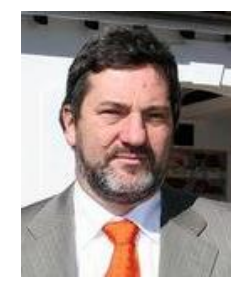

\begin{abstract}
Within a global context, local government in New Zealand occupies an enviable position: it enjoys both a statutorily-defined 'power of general competence' and financial autonomy from central government. However, despite this, voter turnout rates in New Zealand local elections continue to fall as ever fewer New Zealanders engage in this fundamental act of civic engagement. This review article examines the decline in voting over the last four New Zealand local government elections (2010/13/16/19). It aims to do three things: plot the decline; identify and analyse the causes of this decline; and suggest ways in which the decline might be countered. The authors reach the conclusion that local government in New Zealand is at a crossroads - it will either be rejuvenated as a source of local democracy and prosper, or decline into an administrative arm of central government.
\end{abstract}

Keywords: Local government, elections, citizen engagement, New Zealand

DOI: https://doi.org/10.5130/cjlg.vi24.7541

Article History: Received 18/12/20; Accepted 31/05/21; Published 28/06/21

Citation: Commonwealth Journal of Local Governance 2021, 24: 79-97, https://doi.org/10.5130/cjlg.vi24.7541

(C) 2021 Andy Asquith, Karen Webster and Andrew Cardow. This is an Open Access article distributed under the terms of the Creative Commons Attribution 4.0 Unported (CC BY 4.0) License (https://creativecommons.org/licenses/by/4.0/), allowing third parties to copy and redistribute the material in any medium or format and to remix, transform, and build upon the material for any purpose, even commercially, provided the original work is properly cited and states its license. 


\section{Introduction}

Every three years New Zealanders participate in local government elections for 78 local authorities. Within most of those local authorities, councillors are elected based on wards (subdivisions), or - in a minority of areas - 'at large'; that is, by the whole electorate. Mayors, however, are in every case directly elected by the whole electorate. Across New Zealand there is a decline in the number of citizens participating in local government elections. Turnout has decreased over the last four decades from a national average of 57\% in 1989, to a low of 38.2\% in 2019 (Beattie 2011; Local Government New Zealand 2019), raising issues of democratic legitimacy in local government (Bush 1995; Cox 2003; Gronlund and Setala 2007). This decline in voting is not reflected at the central government level, which shows voter turnout of $79.8 \%$ (Electoral Commission 2018) and recently $82.5 \%$ in 2020 (Electoral Commission 2020).

It has been argued by Asquith (2012) that local government in New Zealand occupies an enviable international position. At the time of its enactment, the country's Local Government Act (LGA) 2002 formally recognised the role of local government in New Zealand and empowered 'local bodies' (the term for local authorities) to pursue the 'four well-beings'. This is a broad power to act as they see fit within the law to enhance the well-being of their citizens economically, socially, environmentally and culturally. The pursuit of the well-beings (repealed in 2012 but reinstated in 2019) is equated with what has been described as a 'power of general competence' (Perriam 2002; McKinlay 2003; Shand 2019).

Alongside the power of general competence, New Zealand local bodies also enjoy unusually high levels of financial autonomy (Asquith 2012; Shand 2019). Unlike local authorities in jurisdictions such as England, where local governments have also been granted the power of general competence, and Scotland, where they have a power of general well-being, local bodies in New Zealand have also largely been freed from dependence on finance delegated from a higher tier of government. An English local authority, for example, is dependent on grants of various kinds from central government for in excess of $80 \%$ of its income; by contrast, a New Zealand local body will raise over $85 \%$ of its income locally through property taxes - both general and targeted 'rates' (Department of Internal Affairs 2015). Yet despite the importance of these local taxes, local body elections attract declining numbers of citizens and engagement in the democratic process is decreasing.

In this review the authors draw on extant literature to explain the influences on voter turnout in New Zealand. We begin with a review of conceptual frameworks concerning voting behaviour internationally and relevant features of New Zealand local government. We then plot the decline in turnout and analyse the causes, before identifying seven specific factors which discourage New Zealand citizens from voting. We conclude with suggestions to strengthen local democracy in New Zealand. 


\section{Conceptual frameworks in a New Zealand context}

The New Zealand non-voter mirrors the international non-voter. According to Foster and Taylor (2019), they are more likely to be from non-European ethnic groups. In national elections, for example, those enrolled in Maori electorates were 14\% less likely to vote (Electoral Commission 2015). General electorates with a high Maori and Pasifika population showed a $9 \%$ lower turnout than average, and New Zealanders of Asian descent had the lowest turnout per capita in the 2008 and 2011 elections. Nonvoters also tended to be younger, with $42 \%$ of 18-24-year-olds not voting in the 2011 election (Statistics New Zealand 2014). In 2017, non-voting of this age cohort decreased by $6.5 \%$, preceded by decreases in 25-29-year-olds and 30-34-year-olds of 5.5\% and 3.5\% respectively (Electoral Commission 2018). Alongside this, New Zealand non-voters were more likely to have low incomes and fewer assets, and to be unemployed and to live in rural areas. Foster and Taylor (2019) highlighted that many of these characteristics were intersectional - eg young Maori with a low standard of living, or living rurally, were less likely to vote (Electoral Commission 2015; Foster and Taylor 2019).

The international literature highlights a range of concepts that help to explain these observations and influence voter turnout at local elections. They include in particular:

- 'rational choice' theory - whether elections are seen to matter

- 'youth footprint' theory - the experience of young voters' first three elections

- 'social group' theory - the demographic and social nature of electorates

- 'first- and second-order elections' - the perceived significance of the election within the national framework of democracy.

Rational choice theory (Riker and Ordeshook 1968) suggests that elections must matter in order for voters to participate. It focuses on the costs of participation, generally established by institutional features in the country or region; the perceived benefits, generally arising from the political context and the state of electoral party competition; and the probability of one's vote making a difference. Further, an individual's level of political engagement is determined by their feeling of 'political efficacy' - ie whether they believe that individual political action has an impact on the political process (Campbell et al. 1954). The advocates of rational choice theory assert that the higher the degree of efficacy, the more likely it is that an individual will vote.

Youth footprint theory was advanced by Franklin (2004). He argued that a significant change in established democracies was the swelling of electorates in most Western countries from the late 1960s, as a result of the 'baby boomer' generation reaching voting age. Franklin also observed that newer cohorts were "... more responsive to changes in the character of elections, and the relative size of this group strongly affects turnout by changing the proportion of the electorate that responds to changes in the elections' character" (p. 210). This theory has been supported by multi-country longitudinal data showing increasing cohorts of new voters as the electoral age lowered (Franklin 2004) and a tendency 
for "incoming cohorts to retain the habit of higher or lower turnout gained in their first elections" (p. 60). Such a finding tends to support anecdotal evidence that establishing voting habits early is a successful strategy to increase turnout. The disenfranchisement of younger voters leading to a trend in declining turnout was attributed to a socialising effect at a time when they were establishing themselves in society, and not yet in a position to perceive political benefits. This age effect has influenced voting patterns over a long period of time, and over 20-30 years could account for the trend of declining turnout (Ellis 2006).

In New Zealand's case, the findings of Vowles (2010), showing turnout among youth has not declined between successive generations, cast some doubt on the applicability of 'youth footprint' theory in national elections. On the other hand, the New Zealand literature supports the international concept of social group theory as a contributor to voter behaviour in terms of age, ethnicity, income and rural/urban character (Department of Internal Affairs 2010, 2013; Drage and Webster 2016; Foster and Taylor 2019).

The concept of first- and second-order elections was advanced by Reif and Schmitt (1980) in their analysis of European elections. First-order elections are those offering voters a critical choice of who should govern a country. Second-order elections are seen as less important, because, while open to influence by national party politics, they determine the outcome for lesser offices such as the roles of regional and local officials. Reif and Schmitt suggest that lower levels of voter turnout in municipal elections are explained by less being at stake. If we accept that the concept of first- and second-order elections advanced by Reif and Schmitt (1980) is a valid one, it seems logical that the rational choice theory and its corollary concern of political efficacy (Franklin 2004; Vowles 2010), will heavily influence local government election turnouts.

Commentators in New Zealand (Electoral Commission 2014, 2015; Drage and Webster 2016), have argued that electoral institutions, ${ }^{1}$ and elector knowledge about elections and candidates, are also important influencers of voter turnout at local elections. The New Zealand Local Government Commission (2008) and successive Electoral Commission surveys (Electoral Commission 2015, 2018) highlighted elector apathy and lack of effort as reasons for non-voting. They note as frequently cited factors electors claiming they are too busy or that they ran out of time to vote. Institutional arrangements (see footnote 1), the nature and scale of elections and the resulting complexity were also cited as barriers to voting. In addition, the timing of elections with respect to school holidays and the three-week election period (which was seen as too long), were identified as problematic (Department of Internal Affairs 2010).

\footnotetext{
${ }^{1}$ The Electoral Act 2001 provides for: elections to be held 'at large' (across the whole electoral area) or by ward (a division of the electoral district); councils to be free to choose either 'first past the post' or 'single transferable vote' (a proportional system) as the electoral system; and the establishment of Maori wards.
} 
The next section of this paper will discuss the relationship between central party politics at the national level and in local government in New Zealand's main centres.

\section{Significant features of New Zealand local government}

Until 1989, New Zealand had around 850 multipurpose regional and local authorities (Derby 2016). Local government reforms in 1989 significantly reduced the number of local bodies to 86. By 2021 further reforms had reduced the number to 78 . However, it is the 61 local authorities (district and city councils) and six unitary authorities (councils holding both local and regional powers) that are of interest here. The direct election of mayors in those bodies has been observed to have a significant impact on the media profile of an electoral cycle, and hence voter turnout, compared with the 11 regional councils which appoint a chairperson from amongst the elected councillors.

A common rationale for voting in local elections is that, as the tier of government closest to the populace, local government has great meaning and relevance to the citizenry (Wilson and Game 2012; Drage and Cheyne 2016). Local government development in New Zealand has been described as one of 'stakeholder democracy', in that it was landowners who were first granted the vote in local government (Hill 2003). According to Hill (2003), the long-running impression created among the voting public was one of local government in New Zealand being for the 'protection of the ratepayers' (ie those people directly paying property taxes). This impression was reinforced for decades by continued reference to 'ratepayers' in speeches by local government politicians in New Zealand, notwithstanding a law change in the 1890s that opened up voting rights to all residents of a local government district. Even in 1950, the prime minister of the day, Sidney Holland, proclaimed in parliament that New Zealand was a property-owning democracy. Hence the enduring view subsists that property owners are the primary stakeholders in local government in New Zealand.

Another relevant consideration is the high ratio of citizens to elected representatives (councillors and mayors) in local government. Put in an international context, New Zealand presents as a significant statistical outlier, and the high ratio increases the distance between voters and their representatives. Table 1 below illustrates this position.

Table 1: Citizens per local elected representative - international comparison

\begin{tabular}{|l|c|}
\hline Country & Citizens/elected local representative \\
\hline Austria & 210 \\
\hline Finland & 418 \\
\hline Denmark & 1,161 \\
\hline New Zealand & 5,530 \\
\hline Auckland $^{2}$ & 8,824 \\
\hline
\end{tabular}

Source: Reid (2016) 2 The table includes Auckland, as it is by far the largest city in New Zealand (population approximately 1.5
million, one-third of the national total) and is governed by a city council. 


\section{The role of party politics}

Party politics undoubtedly has a socio-psychological effect (Greene 2004; Hornung et al. 2019) on voter behaviour in local government. Bush (1995) commented upon the long-standing popular view that "politics contaminates the pure air of local government" (p. 260), and the effect it has had on many voters in New Zealand over the decades. In New Zealand, citizens have since the 1980s flocked to the banner 'Keep Politics out of Local Government', an irrational slogan that nonetheless expresses repugnance for the idea of central government party politics influencing local governance (Bush 1980, p. 178). Bush (1995) sees the irrationality of this view, as he describes politics as "the process by which resources are allocated... who gets what, when, how and why" (p. 260). It follows that politics, in this sense, is as prevalent in local government as it is in central government; but, as Bush argues, the object of disapproval in New Zealand has been party politics of a polemic nature as seen in central government elections. However, Bush offers no rationale for why political parties have been unwanted in local government. In fact, in recent times party affiliation at the local level has been on the rise in New Zealand's two largest cities (Webster et al. 2019a, 2019b). Between 2007 and 2016, the number of candidates affiliating overtly to a political party doubled in Auckland (from 15\% to 38\%) and Christchurch (11\% to $26 \%$ ) (Webster et al. 2019b).

Party politics at the local level simplifies the voting process by assisting electors to sort out policy pledges (Bush 1980), and he notes that "voters appreciate the cues given by candidate affiliations" (Bush 1995, p. 264). It seems clear that political parties can offer a broader choice of candidates and, if they are elected in sufficient numbers, provide some accountability on the delivery of policy pledges. It is also well acknowledged in New Zealand and internationally that local politics can serve as a 'stepping-stone' for candidates seeking experience in grass-roots politics and campaigning before contesting a central government seat (Copus 1997; Copus and Erlingsson 2012; Webster et al. 2019b).

Asquith (2012, p. 81) described the apparent lack of overt (party) political activity in New Zealand local government as one of its most distinctive features. Alongside this he acknowledged what he termed 'covert' political activity, for example the centre-right National Party masquerading as the group Citizens and Ratepayers, and the centre-left as the group City Vision. Interestingly, though, there is evidence showing that in the 2010 local elections candidates who affiliated overtly to a political party were three times as likely to be elected as independent candidates, and twice as likely as candidates associated with a local group (Webster et al. 2019a).

The number of candidates failing to disclose party-political affiliations has not been quantified in the recent history of New Zealand local government. However, there have been a number of high-profile mayoral candidates who have had a history of political party leadership roles, but who have not been open about their past political activity - the current mayors of Auckland, Christchurch and Wellington being cases in point. Drawing on the work of Putnam $(1993,2000)$ the authors argue that this lack of 
transparency can undermine the trust that voters have in the local democratic process and is likely to impact on their decision whether to vote or not.

\section{Patterns of declining voter participation}

The recent decline in voter participation in local body elections is summarised in Table 2 below, which also highlights the number of uncontested mayoral elections out of the 67 eligible local authorities.

Table 2: Overall local voter participation and unopposed mayors

\begin{tabular}{|l|c|c|c|c|c|c|c|}
\hline Year & $\mathbf{2 0 0 1}$ & $\mathbf{2 0 0 4}$ & $\mathbf{2 0 0 7}$ & $\mathbf{2 0 1 0}$ & $\mathbf{2 0 1 3}$ & $\mathbf{2 0 1 6}$ & $\mathbf{2 0 1 9}$ \\
\hline Turnout \% & 48 & 46 & 44 & 49 & 41 & 42 & 41.4 \\
\hline Unopposed mayors (no.) & 8 & 13 & 13 & 9 & 8 & 9 & 6 \\
\hline Unopposed mayors (\%) & 11.9 & 19.4 & 19.4 & 13.4 & 11.9 & 13.4 & 9 \\
\hline
\end{tabular}

Source: Local Government New Zealand (2019); ${ }^{3}$ Department of Internal Affairs (2010, 2013)

There are three features of interest regarding the overall decline in voter turnout. Firstly, the number of uncontested mayoral elections has remained relatively low. It is widely believed that a higher number of mayoral elections would have increased voter interest and levels of participation. In 2006, the Department of Internal Affairs noted that "mayoral contests have a strong effect on turnout, especially where the mayoralty was strongly contested and the incumbent mayor was subsequently defeated" (Department of Internal Affairs 2006, p. 26). While the data presented in Table 2 may be seen to cast some doubt on this proposition, it is supported by other evidence on the importance of contestability, as discussed below.

Secondly, the majority of New Zealand local elections since 1989 have been conducted by postal voting. Twenty-five years ago, Bush (1995) argued the past decline in voter participation levels was due to the requirement to visit a polling station to cast a vote, with the adoption of postal voting being seen as the solution. It was hoped the downward trend could be reversed. However, Table 2 shows the continuing decrease in turnout since 2001 (and indeed voter turnout has fallen steadily since 1989), with the exception of 2010 when the introduction of the new unitary Auckland Council, amid much media hype, bucked the general trend.

A further point of interest is the clear evidence that voter turnout in smaller and rural local authorities is significantly higher than in larger urban ones (Department of Internal Affairs 2013; Geys 2006). This trend is reported by Reid (2016) and clearly demonstrated by Local Government New Zealand's data from the last four electoral rounds, whereby there is a marked difference of at least $10 \%$ between voter engagement in rural authorities and that in bigger metropolitan councils. This is shown in Table 3.

\footnotetext{
${ }^{3}$ Local Government New Zealand (LGNZ) is the national association that represents elected councillors, not a government department.
} 
Table 3: Voter turnout by metropolitan, provincial and rural local authorities

\begin{tabular}{|l|c|c|c|c|c|}
\hline Voter turnout \% & $\mathbf{2 0 1 0}$ & $\mathbf{2 0 1 3}$ & $\mathbf{2 0 1 6}$ & $\mathbf{2 0 1 9}$ & \% change \\
\hline Metro & 45.0 & 38.0 & 39.3 & 38.2 & -1.2 \\
\hline Provincial & 50.0 & 47.0 & 45.7 & 46.7 & 1.0 \\
\hline Rural & 54.0 & 50.0 & 49.8 & 56.9 & 7.1 \\
\hline National average & 49.0 & 41.3 & 42.0 & 41.4 & -0.7 \\
\hline
\end{tabular}

Source: Local Government New Zealand (2019)

There is also evidence that the ratio of councillors to number of voters, and the total population and geographical size of constituencies, are important factors. Drage and Webster (2016) observe that the New Zealand Department of Internal Affairs statistics have consistently shown an increase in voter participation where councillors represent fewer citizens. This picture is amply illustrated by Table 4, which shows 2019 data from large and small councils.

Table 4: Turnout and councillor/voter representation ratios for large and small councils, 2019

\begin{tabular}{|l|c|c|c|c|}
\hline Council & Turnout \% & Councillors & Voters & $\begin{array}{c}\text { Representation } \\
\text { ratio }\end{array}$ \\
\hline Auckland & 35.3 & 20 & $1,065,501$ & 53,275 \\
\hline Wellington & 39.9 & 14 & 148,177 & 10,584 \\
\hline Christchurch & 41.1 & 16 & 248,605 & 15,538 \\
\hline Hamilton & 39.4 & 12 & 102,673 & 8,556 \\
\hline Mackenzie & 60.6 & 6 & 3,115 & 519 \\
\hline Westland & 63.9 & 8 & 5,953 & 744 \\
\hline Kaikoura & 61.4 & 7 & 2,736 & 391 \\
\hline Waimate & 52.2 & 8 & 5,463 & 683 \\
\hline
\end{tabular}

Source: Local Government New Zealand (2019)

Drage and Webster (2016) observed that in 2013 "the highest voter turnout in cities was in Nelson (52.2\%), Napier (47.8\%) and Invercargill (46\%), all cities with representation ratios of 3,000 to 3,500" (p. 144). Similarly, Reid (2016) notes that councils with smaller representation ratios tend to have higher levels of voter turnout - something which is reflected in Local Government New Zealand's own statistics. These institutional facets of New Zealand local government support the rational choice argument discussed earlier, namely that elections must be seen as relevant and meaningful to voters' daily lives in order for them to turn out - a point reinforced by the data contained in Table 4.

\section{Opportunities for improvement}

Acknowledging the large body of research supporting rational voter theory and suggesting social structure as an explanation for the generational footprint of lower turnout in New Zealand and as a possible explanation for the decrease in voting in recent decades, this paper proposes a further seven factors - both institutional and psychosocial - which have the potential to hinder participation levels in local elections in New Zealand. They are: (1) lack of contestability; (2) candidate party-political affiliation; (3) the complication of multiple electoral systems; (4) competency of local candidates; (5) a 
lack of council and candidate information; (6) the visibility of incumbent councillors; and (7) the cost of participating in local elections. The authors suggest that, taken together, these may significantly impede and discourage citizen engagement and participation in local elections in New Zealand.

\section{Lack of contestability}

Elections are contests and are a fundamental expression of local democracy (Beattie 2011). No one should be 'elected' unopposed. However, in New Zealand in 2016 nine incumbent mayors were elected unopposed (see Table 2) - including one who had not had a challenger since first being elected in 2004 (ie over a cycle of four triennial elections). This speaks to the rational choice argument that elections need to matter to mobilise voters: if a mayor is popularly elected and recognised as the leader and spokesperson for an area, and is a focus of media and campaign activity, then a mayoral election is likely to attract voter participation (Department of Internal Affairs 2006). While the New Zealand data presented in Table 2 does raise questions about this reasoning, the theory is supported by a large body of international research which has found that failure to have a mayoral election has a negative influence upon overall voter turnout (Beattie 2011; Blais and Rubenson 2012; Wilson and Game 2012).

Moreover, the importance of contestability is starkly illustrated by the races for the Auckland mayoralty since 2010. Auckland is New Zealand's largest local authority with a population of 1.5 million, serving a third of the country's inhabitants. Even a slight increase or decrease in voting levels in Auckland can significantly influence the national turnout figures. The comparable elections for the position of Auckland mayor in 2010 and 2013 are presented as an example. In 2010, a pan-Auckland unitary council was created following the Royal Commission on Auckland Governance and the election for mayor was seen as being one of national significance and importance. Although some 22 candidates ran for the post in 2010, it was widely accepted in the media that it was a 'two-horse race' between the right-leaning, former National Party minister and last mayor of the former central Auckland City John Banks, and the left-leaning Len Brown, mayor of the former Manukau City in the south of the Auckland conurbation (Stuff 2010). Such was the media and general interest in the election, won by Brown, that the turnout of $51 \%$ (Department of Internal Affairs 2013) bucked the national trend.

The 2013 Auckland local government election presented a different case. Brown, as the first mayor of the 'new' Auckland, looked to be hard to defeat and there was no high-profile centre-right candidate. Brown was re-elected, but with a decreased voter turnout of 35.5\% (Local Government New Zealand 2019). This pattern was repeated in 2016. However, in 2019, the mayoral race was a 'multi-horse' contest between two former Labour cabinet colleagues, Phil Goff - the incumbent mayor and former party leader - against the challenge of John Tamihere. The robust mayoral competition contributed to a $4 \%$ lift in voter turnout over the previous election. 


\section{Political affiliation}

The second influencing factor identified by this paper relates to candidates' reticence to declare a 'political' affiliation, a significant issue affecting local body elections in New Zealand's largest centres (Webster et al. 2019b). The country has an image of being at the forefront of environmental recycling. Equally apparent is the constant 'recycling' back and forth of politicians between central and local government. While there are a small number of local politicians who make the 'step up' into parliament, there have been many former central government politicians fashioning a second political career in local government (Hehar 2016; Hurley 2019). While in parliament, these candidates have all been representatives of a major political party, but in local elections they claim to be 'independent', even though it appears that few, if any, relinquish their political party membership. This undermines perceptions of the transparency and credibility of local government. The idea of being able to shed one's political values and beliefs simply because of the desire to be seen as independent, is something we, the authors, find hard to accept.

\section{Multiple electoral systems}

A third factor is the use of multiple electoral systems. The present research suggests central government has inadvertently complicated the electoral system, with the unintended outcome of alienating voters. The whole process of elections in New Zealand is complicated and confusing - with electors having to be familiar with, understand, and participate in three different systems simultaneously (Beattie 2011; Drage and Webster 2016; Reid 2016). For national parliamentary elections, voters face a system of mixed-member proportional representation (MMP). For local body elections, individual authorities may utilise either the 'first past the post' (FPP) or 'single transferable vote' (STV) system. Only a minority of local authorities (seven out of 67) used the STV system in 2013 and this number was in decline (Hayward 2016). There has, however, been a minor reversal recently, with 11 councils using STV in 2019, and in 2020 three additional councils voting to adopt STV for the 2022 local elections, bringing the total number of district and city councils using this method to 14 out of 67 .

To coincide with the local body elections, every three years New Zealanders also elect members to their district health boards (DHBs). These elections all use the STV system. To complicate matters even further, ballot papers for the elections for mayor, the local body and the DHB are contained in a single document. Thus within one document electors may need to understand and differentiate between two wholly different electoral systems. Elections may also be held for other minor bodies, such as alcohol licensing trusts. This has the result of creating complex ballot papers which, already half a century ago, Walker (1966) argued was a factor likely to alienate would-be electors. The authors do note that the central government's recent Health and Disability Review (2020) recommended the abolition of DHB elections. Such a move may reduce the level of confusion, if the majority of councils persist with FPP. 


\section{Competence of local candidates}

Fourth, in New Zealand the lack of competence of individuals standing for election to a local body is concerning, given the governance roles and responsibilities which mayors and councillors are expected to fulfil. This issue has 'come to a head' with recent events in three major councils: Tauranga, Invercargill and Wellington, all of which have had significant failures in governance. In Tauranga, the Department of Internal Affairs (DIA) replaced the council with Commissioners; in Invercargill Crown observers were appointed to Invercargill City Council; while Wellington is on a DIA 'watch list' and an independent governance reviewer has been appointed and will report in April 2023 to the Minister for Local Government (George and Keogh 2021).

To be eligible to stand in a local government election, a candidate must meet three core criteria: (i) be a New Zealand citizen; (ii) secure nominations from two people on the electoral roll for the local authority in which they want to stand; and (iii) pay a deposit of NZ\$200. This low threshold for entry has the effect of encouraging many candidates unlikely to be successful to stand. For example, the 2010 election for Auckland mayor attracted 21 candidates, of whom only two had a serious chance of victory - something acknowledged by the prime minister at the time, who noted he could "work with either of the two candidates" (Asquith 2015). Meanwhile in Palmerston North, it appears that one recent candidate could have been barred from holding mayoral office due to long-standing mental health issues $^{4}$ (Galuzka 2018). The lack of formal political party involvement in local government elections in New Zealand exacerbates this issue by, in effect, removing a 'quality-control' mechanism in candidate selection such as is found, for instance, in local government elections in the UK (Widdecombe 1986; Bottom and Reiser 2014) and Europe (Aars and Ringkjobt 2005; Bottom and Copus 2011; Copus and Erlingsson 2012).

\section{Council and candidate information}

Fifth, there is a general lack of voter information, both about the councils themselves and about those seeking election to council. Although each council's chief executive is required to produce a preelection report, there is scant public knowledge of either the existence of the report or its content. Often the only way a voter has knowledge of a candidate is if they read the statutorily mandated 'candidate information booklets', which describe in 150 words each candidate's 'platform' and political affiliation. As noted earlier, in New Zealand many candidates describe themselves as an 'independent' or simply ignore identifying their status (Webster et al. 2019a), regardless of previous political affiliation. During the 2016 election campaign the then prime minister even observed that the value to be gained from

\footnotetext{
${ }^{4}$ The Local Electoral Act 2001, s60(4), states: "If the electoral officer receives advice before the close of nominations that a candidate is, or has become, incapable under any Act of holding the office for which he or she is a candidate, that candidate's nomination must be treated in all respects as if it had not been made."
} 
reading the candidate profile booklet was so limited that he never read it, simply voting for those candidates with whom he was familiar (New Zealand Politics Daily 2016).

Finally on this point of candidate 'familiarity', considerable evidence suggests that the way people get to 'know' a candidate in local body elections is if he or she is a well-known figure or has 'been in the job' for a number of years (Bush 1980, 1981; Drage 2008). Once again, with high councillor to population ratios, the lack of political party involvement in local elections is all the more intriguing given the finding of Webster et al. (2019b; 2019a) that clear party affiliation can have a significant beneficial impact on a candidate's chances of electoral success.

\section{Visibility of incumbent councillors}

The sixth factor identified relates to the visibility or otherwise of incumbent councillors. Early work by Bush (1981) highlighted the high success rate amongst incumbent candidates in New Zealand. This pattern was further replicated in the 2008 local elections in the state of Victoria, Australia (Economou 2010) and in local elections in Canada (Sancton 2018). The low turnout of voters in New Zealand local body elections may be attributed in part to the relative invisibility of a councillor once they have been elected. In New Zealand there is no requirement for the elected councillors to hold 'clinics' or 'surgeries', and unlike the position in relation to their member of parliament, a voter may not see an office in their locality for the local councillor/s. Thus the elected members of councils in New Zealand can become virtually invisible to anyone not actively involved in the business of local government. Drage (2008) illustrates this in some detail, arguing that councillors have dual roles - as an elected representative, providing local voice; and alongside this a governance role, determining plans and policies and making some operational decisions. It is worthy of note that since the election of the fourth Labour government in 1984, New Zealand has embraced a neo-liberal 'new public management' model much more enthusiastically than any other country (Kelsey 1995; Martin et al. 1996; Pollitt 2000; Scott 2001; Asquith 2016). As a result, the governance role of a councillor, as opposed to their representative role, is dominant, and is similar to that of a non-executive director in a private sector business (Asquith 2012). As Drage (2008) points out, councillors who challenge this by arguing for a more balanced role, giving greater emphasis to their representative responsibilities, tend to find themselves 'frozen out'.

\section{Cost of participation}

The authors' seventh and final point relates to the cost for candidates of participating in local elections. While the bar for standing for election is low, the ability to run a credible campaign which has impact is a different proposition altogether. The lack of overt party-political activity means that there are no nationally organised and funded election campaigns for local elections. The net effect of this is that candidates are either self-reliant for campaign funding or dependent upon a group of supporters or wealthy benefactors. This applies particularly to mayoral elections in the larger cities. There are nationally-set caps on the amount a candidate may spend in Auckland, and to a lesser extent the other 
major urban areas, but candidates' expenses can still be considerable (Webster et al. 2019a). The cost of seeking election to the Auckland mayoralty can be estimated by the fact that in the two elections of 2010 and 2013 the victor, Len Brown, received two individual campaign donations of NZ\$499,000 and NZ\$273,000. More recently, Phil Goff won the 2016 Auckland mayoralty after spending NZ\$410,814 of the NZ\$604,171 he raised, thus enabling him to bank NZ\$193,357 for his 2019 re-election campaign (Niall 2016). It was also suggested by Orsman (2016) that Goff had raised NZ\$250,000 in a single fundraising dinner for his 2016 campaign.

As such, all except those able to raise substantial funds (in the New Zealand local government context), are excluded from standing and coordinating a large-scale campaign (Orsman 2016). While Auckland is an outlier in terms of New Zealand cities' elections in terms of campaign cost, other big city mayoralties can also be costly ventures. In Palmerston North (one of the five largest metropolitan cities in New Zealand), the mayor was returned in 2019 having spent only NZ\$538, but his initial election campaign in 2016 cost in excess of NZ $\$ 40,000$. Candidate expense returns show an average expenditure of between NZ $\$ 3,000-4,000$ for other elected councillors.

\section{Conclusions: a way forward}

The international literature highlights the importance of the rational voter theory (Franklin 2004): elections must matter and be perceived as important to voters. Age and generational effects, youth footprint theory (Franklin 2004; Vowles 2010), the concept of first- and second-order elections (Riker and Ordeshook 1968; Reif and Schmitt 1980), and social group or network theory may all also have an influence on voter participation in local government elections (Bevelander and Pendakur 2009, 2011; Bhatti and Hansen 2012; Blais and Rubenson 2012). Both the literature and the present study's analysis highlight deterrents to voting arising from the way local elections are conducted in New Zealand. The latest decline in electoral turnout in the 2019 local government elections suggests a need for immediate reform that recognises these influences. Without significant reform, local democracy in New Zealand, specifically citizen engagement in the local electoral process, looks set to continue to decline. The authors propose that the various issues, influences and specific factors highlighted in this paper be addressed across four areas of reform, as follows: (1) enhance the transparency of the party-political nature of local government; (2) strengthen the national collective voice and understanding of local government; (3) introduce compulsory civics education; and (4) make local government and councillors more visible.

An initial positive step towards reinvigorating interest and engagement in local elections would be made if, wherever relevant, the implicit party-political nature of local government is made explicit. This would see enhanced transparency of candidates' political affiliations. In this context, the major political parties need to refrain from running nominally 'independent' candidates, or 'tickets' of candidates under assumed party names, and instead run clearly identifiable party-political representatives. Voters would 
then know the 'true colours' of their candidates. Further, a party selection process would go some way to lifting the calibre of candidates. The most obvious examples here are the Auckland-based 'Citizens and Ratepayers' and 'Auckland Future' tickets, which are National Party affiliated; and 'City Vision', which is the declared centre-left-aligned political ticket. As reported earlier, Webster et al. (2019a) have demonstrated, in Auckland at least, that candidates explicitly identified with a major party have a greatly enhanced chance of electoral success - and the pattern appears to be to some extent replicated in other large New Zealand cities. An example is Palmerston North, which has a 'progressive' block of four councillors (out of 16), with two Green Party and two Labour Party representatives, elected on explicit political party platforms. Elsewhere, in the Wellington region a small, but increasing, number of Labour Party councillors are being elected.

Secondly, the collective voice of local government needs to be heard more often. Many New Zealanders have little or no understanding of the positive impacts their local authority has on their daily lives. Towards the close of the 2013 campaign, the then CEO of Local Government New Zealand, Malcolm Alexander, published an opinion piece in the New Zealand Herald which extolled the virtues of local government and the importance of citizens engaging in the democratic process (Alexander 2013). Unfortunately, this article was too little and too late in the electoral process. Since then, there has not been a concerted campaign to reinforce the message Alexander was trying to communicate.

To ensure that the 'youth footprint' supports voter turnout, this paper advocates strengthening and better resourcing civics education programmes, plus adding new initiatives that teach the value of civic participation and encourage young people to exercise their vote. The authors note the sombre tone struck by Ellis (2006, p. 16):

It has indeed been suggested that the first three elections for which a voter is qualified are of defining importance, and that if voting does not become a routine event early in a person's life, the potential for that individual to participate consistently may be lost.

This is a challenge which the New Zealand Political Studies Association (2020) is embracing, alongside the Ministry of Education's own initiatives in Wellington (Ministry of Education 2020). While specific civics education would be beneficial, the authors acknowledge the potential for tensions between the neo-liberal elite within New Zealand and a 'civics-focused' population, which would be able to assess and critique the dismantling of traditional institutions of governance from an informed perspective (Kelsey 1995).

Finally, New Zealand needs to re-evaluate the current approach to 'second-order' elections: making both local elections and candidates more visible, taking note of the observations of Reif and Schmitt (1980) cited earlier, and recognising the arguments for political efficacy. To avoid the scenario of declining voter turnout translating into an inexorable decline in local democracy, councillors and mayors must be much more visible and their responsibilities better understood by the populace. They need to escape the shackles of the town hall and reinforce the important role of local government, which 
arguably has more impact upon our daily lives than any other level or institution of the state. This reorientation would be about providing voters with needed information, not electoral propaganda. Central government needs to step up and take the lead, in partnership with Local Government New Zealand. Taking Auckland as an example, it would be immensely influential if government ministers were to be constructive about the role of Auckland Council and hence about the importance of local elections.

If significant cultural change does not occur at both the local and national levels of government, engagement and trust in local government will continue to languish and election turnout will be in terminal decline. This risks moving local government from a functioning sphere of democracy to an administrative arm or agency of central government. Clearly, traditional methods of getting political messages across no longer have the same impact. For many citizens, social media has replaced the evening news. Yet, for example, the Scottish independence referendum in the UK in 2014 showed that when young people are engaged with an issue they see as important and relevant to them, they participate in record numbers with, in this case, over $80 \%$ of those eligible to vote doing so (McSmith 2014). Galvanising this engagement is the key task we face in New Zealand.

Given this background, the words of Jim Hacker from the British television comedy Yes Prime Minister - talking about English local government - seem most apt:

Only about $25 \%$ of the electorate vote in local elections. And all they do is treat it as a popularity poll on the political leaders [in central government] ... Nobody knows who their local councillor is. And the councillors know nobody knows who they are. Or what they do. So they spend four totally unaccountable years on a publicly-subsidised ego trip, handing out ratepayers' hard-earned money... (Lynn and Jay 1989, p. 134).

As this paper was being finalised, New Zealand's Minister of Local Government, the Honourable Na Nanaia Mahuta, announced a review entitled 'The Future of Local Government'. This is the first fundamental, root-and-branch examination of the scope and scale of local government since the reforms of the late 1980s. Central to this review will be many of the issues identified in this paper: citizen engagement; participation; and how to achieve reinvigorated, vibrant local democracy. The review panel is scheduled to present its report in April 2023. The authors await its findings with great trepidation and hope this paper will be of interest to its members.

\section{Declaration of conflicting interest}

The authors declared no potential conflicts of interest with respect to the research, authorship, and/or publication of this article.

\section{Funding}

The authors received no financial support for the research, authorship, and/or publication of this article. 


\section{References}

Aars, J. and Ringkjobt, H.-E. (2005) Party politicisation reversed? Non-partisan alternatives in Norwegian local politics. Scandinavian Political Studies, 28, 161-181. https://doi.org/10.1111/j.0080-6757.2005.00126.x

Alexander, M. (2013) Have a say on how your city is run. New Zealand Herald, 2 October 2013. Available at: https://www.nzherald.co.nz/nz/malcolm-alexander-have-a-say-on-how-your-city-isrun/RWOLU6ZGD5Z3YFZIHUEGGPGLDU/ [Accessed: 20 January 2021].

Asquith, A. (2012) The role, scope and scale of local government in New Zealand: Its prospective future. Australian Journal of Public Administration, 71, 76-84. https://doi.org/10.1111/j.14678500.2012.00751.x

Asquith, A. (2015) Auckland: Super city or super cock-up? Paper presented at New Zealand Political Studies Association Annual Conference, Massey University, Palmerston North, New Zealand, 30 November-3 December 2015.

Asquith, A. (2016) Public sector management in New Zealand's local government. In: Drage, J. and Cheyne, C. (eds) Local government in New Zealand: Challenges and choices, (pp. 205-218). Auckland: Dunmore Publishing Ltd.

Beattie, G. (2011) A glass half full or half empty? In: Drage, J., Cheyne, C. and Mcneill, J. (eds) Along a fault line: New Zealand's changing local government landscape, (pp. 91-105). Auckland: Dunmore Publishing Ltd.

Bevelander, P. and Pendakur, R. (2009) Social capital and voting participation of immigrants and minorities in Canada. Ethnic and Racial Studies, 32, 1406-1430. https://doi.org/10.1080/01419870802298447

Bevelander, P. and Pendakur, R. (2011) Voting and social inclusion in Sweden. International Migration, 49, 67-92. https://doi.org/10.1111/j.1468-2435.2010.00605.x

Bhatti, Y. and Hansen, K.M. (2012) Leaving the nest and the social act of voting: Turnout among first time voters. Journal of Elections, Public Opinion and Parties, 22, 380-406. https://doi.org/10.1080/17457289.2012.721375

Blais, A. and Rubenson, D. (2012) The source of turnout decline: New values or new contexts? Comparative Political Studies, 46, 95-117. https://doi.org/10.1177/0010414012453032

Boston, J., Martin, J., Pallot, J. and Walsh, P. (1996) Public management. The New Zealand model. Melbourne: Oxford University Press.

Bottom, K. and Copus, C. (2011) Independent politicis: Why seek to serve and survive as an independent councillor. PPA, 26, 279-305. https://doi.org/10.1177/0952076710378547

Bottom, K. A. and Reiser, M. (2014) Still want to party? An assessment of party-politicization in directlyelected mayoral authorities in England and Germany's North Rhine-Westphalia. Public Money \& Management, 34, 339-346. https://doi.org/10.1080/09540962.2014.945799

Bush, G. (1980) Local government and politics in New Zealand. Auckland: George Allen and Unwin Australia Pty Ltd.

Bush, G. (1981) Incumbency in the 1980 local body election. Political Science, 33, 211-216. https://doi.org/10.1177/003231878103300210

Bush, G. (1995) Local government and politics in New Zealand. Auckland: Auckland University Press.

Campbell, A., Gurin, G. and Miller, W. (1954) The voter decides. Evanston, USA, Row Peterson.

Copus, C. (1997) The local councillor and party loyalty. Policy and Politics, 27, 309-324. https://doi.org/10.1332/030557399782453064

Copus, C. and Erlingsson, G. (2012) Parties in local government: A review. Representation, 48, $235-247$. https://doi.org/10.1080/00344893.2012.683489

Cox, M. (2003) When trust matters: Explaining differences in voter turnout. Journal of Common Market Studies, 41, 757-770. https://doi.org/10.1111/1468-5965.00444

Department of Internal Affairs. (2006) Local government rates inquiry: Terms of reference. Wellington: Department of Internal Affairs. 
Department of Internal Affairs. (2010) Local authority election statistics 2010. Wellington: New Zealand Government.

Department Of Internal Affairs. (2013) Local authority election statistics 2013 [Online]. Wellington, New Zealand Government. Available at: https://www.dia.govt.nz/diawebsite.nsf/wpg_URL/Services-LocalElections-Local-Authority-Election-Statistics-2013?OpenDocument [Accessed 23 April 2015].

Department Of Internal Affairs. (2015) About local government [Online]. New Zealand Government. Available at: http://www.localcouncils.govt.nz/lgip.nsf/wpg_url/about-local-government-index [Accessed 2 October 2015].

Derby, M. (2016) Local and regional government - Reforming local government [Online]. Te Ara - the Encyclopedia of New Zealand. Available at: http://www.teara.govt.nz/en/local-and-regionalgovernment/page-5 [Accessed 11 December 2016].

Drage, J. (2008) A balancing act: Decision-making and representation in New Zealand's local government. Wellington: Institute of Policy Studies, School of Government, Victoria University of Wellington.

Drage, J. and Cheyne, C. (2016) Local government in New Zealand: Challenges and choices. Auckland: Dunmore Publishing Ltd.

Drage, J. and Webster, K. (2016) Political representation: The councillor's role. In: Drage, J. and Cheyne, C. (eds) Local government in New Zealand: Challenges and choices, (pp. 140-151). Auckland: Dunmore Publishing Ltd.

Economou, N. (2010) Parties, participation and outcomes: The 2008 Victorian local government elections. Australian Journal of Political Science, 45, 425-436. https://doi.org/10.1080/10361146.2010.499164

Electoral Commission. (2014) Voter and non-voter satisfaction survey 2014 general election. Wellington: Electoral Commission.

Electoral Commission. (2015) Report into the 2014 general election. Prepared by TNS New Zealand for the Electoral Commission. Wellington: New Zealand Government.

Electoral Commission. (2018) Report into the 2017 general election. Prepared by TNS New Zealand for the Electoral Commission. Wellington: New Zealand Government.

Electoral Commission. (2020) Report of the Electoral Commission on the 17 October 2020 general election and referendums. Wellington: Electoral Commission.

Ellis, A. (2006) Engaging the electorate: Initiatives to promote voter turnout from around the world. Including voter turnout data from national elections worldwide, 1945-2006. Stockholm: International IDEA.

Foster, J. and Taylor, D. (2019) Voter turnout decline in New Zealand: A critical review of literature and suggestions for future research. New Zealand Sociology, 34, 1-17.

Franklin, M.N. (2004) Voter turnout and the dynamics of electoral competition in established democracies since 1945. New York: Cambridge University Press. https://doi.org/10.1017/CBO9780511616884

Galuszka, J. (2018) Council candidate Ross Barber unfit to control his own affairs. Stuff, 24 August 2018.

George, D. and Keogh, B. (2021) Independent probe into Wellington City Council starting 'immediately', reviewer says. Stuff, 27 February 2021.

Geys, B. (2006) Explaining voter turnout: A review of aggregate-level research. Electoral Studies, 637-663. https://doi.org/10.1016/j.electstud.2005.09.002

Greene, S. (2004) Social identity theory and party identification. Social Science Quarterly, 85, 136-153. https://doi.org/10.1111/j.0038-4941.2004.08501010.x

Gronlund, K. and Setala, M. (2007) Political trust, satisfaction and voter turnout. Comparative European Politics, 5, 400-422. https://doi.org/10.1057/palgrave.cep.6110113

Hayward, J. (2016) Local government and proportional representation. In: Drage, J. and Cheyne, C. (eds) Local government in New Zealand: Challenges and choices, (pp. 130-139). Auckland: Dunmore Publishing Ltd.

Health and Disability System Review. (2020) Health and disability system review - final report - Pürongo Whakamutunga. Wellington: HDSR.

Hehar, L. (2016) Little problem with Phil Goff running for mayor while an MP. Stuff, 29 November 2016. 
Hill, M. (2003) Public policy in the community. Hampshire: Palgrave MacMillan.

Hornung, J., Bandelow, N.C. and Vogeler, C.S. (2019) Social identities in the policy process. Policy Sciences, 211-231. https://doi.org/10.1007/s11077-018-9340-6

Hurley, B. (2019) John Banks hires powerful campaign team as he eyes a run for Auckland mayor. Stuff, 14 July 2019.

Kelsey, J. (1995). The New Zealand experiment. Auckland: AUP.

Local Government Commission. (2008) Review of the Local Government Act 2002 and Local Electoral Act 2001: Summary Report. Wellington: Local Government Commission.

Local Government New Zealand. (2019) Final voter turnout 2019 [Online]. Wellington: Local Government New Zealand. Available at: https://www.lgnz.co.nz/vote2019/voters/final-voter-turnout-2019/ [Accessed 6 March 2020].

Lynn, J. and Jay, A. (1989) The complete Yes Prime Minister. London: BBC Books.

McKinley, P. (2003) Adapting to new powers of general competence: Examining the implications of new freedoms and constraints under the new legislation. Successfully Implementing Local Government Reform Conference. Wellington.

McSmith, A. (2014) The Scottish referendum results: Huge turnout bolsters case for voting. Independent. Available at: https://www.independent.co.uk/news/uk/scottish-independence/scottish-referendum-resultshuge-turnout-bolsters-case-voting-16-9745081.html [Accessed 20 January 2021].

Ministry of Education. (2020) Civics and citizenship education: Teaching and learning guide. Wellington: Ministry of Education.

New Zealand Political Studies Association. (2020) Civics, citizenship and political literacy working group [Online]. NZPSA. Available at: https://nzpsa.co.nz/civics-citizenship-and-political-literacy [Accessed 2 December 2020].

New Zealand Politics Daily. (2016) What's wrong with local elections? NBR, 27 September 2016.

Niall, T. (2016) Goff has $\$ 200 \mathrm{k}$ left in campaign kitty after mayoral win. Radio New Zealand, 12 December 2016.

Orsman, B. (2016) Chinese dinner adds \$250,000 to Phil Goff's war chest. New Zealand Herald, 19 September 2016.

Perriam, F. (2002) The powers of general competence: The coming of age of local government or the rise and rise of bureaucratic control. Kellogg/Primary Industry Council Rural Leadership Programme. Lincoln University.

Pollitt, C. (2000) Is the emporer in his underwear? Public Management - An International Journal of Research and Theory, 2, 181-200. https://doi.org/10.1080/14719030000000009

Putnam, R.D. (1993) Making democracy work: Civic traditions in modern Italy. New Jersey: Princeton University Press. https://doi.org/10.2307/j.ctt7s8r7

Putnam, R.D. (2000) Bowling alone: The collapse of American community. New York: Simon \& Schuster. https://doi.org/10.1145/358916.361990

Reid, M. (2016) Local authority turnout: What's the story? Policy Quarterly, 12, 3-9. https://doi.org/10.26686/pq.v12i4.4625

Reif, K. and Schmitt, H. (1980) Nine second order elections - A conceptual framework for the analysis of European election results. European Journal of Political Research, 8, 3-44. https://doi.org/10.1111/j.1475-6765.1980.tb00737.x

Riker, W. and Ordeshook, P. (1968) A theory of the calculus of voting. American Political Science Review, 62, 25-42. https://doi.org/10.1017/S000305540011562X

Sancton, A. (2018) What happened to incumbent councillors in Greater Sudbury and London? The role of the Ontario ombudsman's reports on alleged secret meetings. In: Breux, S. and Couture, J. (eds) Accountability and responsiveness at the municipal level: Views from Canada, (pp. 132-152). Ontario: McGill-Queen's University Press. https://doi.org/10.2307/j.ctv2n7pbt.10

Scott, G. (2001) Public sector management in New Zealand: Lessons and challenges. Canberra: ANU. 
Shand, D. (2019) Local government role \& autonomy: Some additional perspectives. A paper prepared for the Policy Observatory. Auckland: Auckland University of Technology.

Statistics New Zealand. (2014) Non-voters in 2008 and 2011 general elections: Findings from New Zealand General Social Survey. Wellington: New Zealand Government.

Stuff. (2010) Len Brown beats John Banks in super-race. Stuff, 9 October 2010.

Vowles, J. (2010) Electoral system change, generations, competiveness and turnout in Newealand, 1963-2005. British Journal of Political Science, 40, 875-895. https://doi.org/10.1017/S0007123409990342

Walker, J.L. (1966) Ballot forms and voter fatigue: An analysis of the office block and party column ballots Midwest Journal of Political Science, 10, 448-463. https://doi.org/10.2307/2108922

Webster, K., Asquith, A., Rohan, M., Cardow, A. and Majavu, M. (2019a) Auckland, New Zealand - fair game for central party politics. Local Government Studies, 45, 569-592. https://doi.org/10.1080/03003930.2019.1584558

Webster, K., Greaves, L., Asquith, A. and Cardow, A. (2019b) Its my party and I'll lie if I want to... Local political affiliation in NZ's main centres. Paper presented at the New Zealand Political Studies Association Annual Conference, University of Canterbury, Christchurch, New Zealand, 27-29 November 2019.

Widdecombe, D. (1986) The conduct of local authority business: Report of the Committee of Inquiry into the Conduct of Local Authority Business. London: HMSO.

Wilson, D. and Game, C. (2012) Local government in the United Kingdom. 5th ed. Basingstoke, McMillan. https://doi.org/10.1007/978-0-230-35667-2 